\title{
The harvestmen fauna (Arachnida: Opiliones) of the Parque Estadual Carlos Botelho, and the Floresta Nacional de Ipanema, São Paulo, Brazil
}

\author{
Leonardo Palloni Accetti Resende ${ }^{1}$, Ricardo Pinto-da-Rocha ${ }^{2,3}$ \& Cibele Bragagnolo $^{2}$ \\ ${ }^{1}$ Universidade Paulista - UNIP, Av. Independência, 210, Éden, CEP 18087-101, Sorocaba, SP, Brasil \\ ${ }^{2}$ Departamento de Zoologia, Instituto de Biociências, Universidade de São Paulo - USP, \\ CP 11461, CEP 05422-970, São Paulo, SP, Brasil \\ ${ }^{3}$ Corresponding author: Ricardo Pinto da Rocha, e-mail: ricrocha@usp.br
}

RESENDE, L.P.A., PINTO-DA-ROCHA, R. \& BRAGAGNOLO, C. The harvestmen fauna (Arachnida: Opiliones) of the Parque Estadual Carlos Botelho, and the Floresta Nacional de Ipanema, São Paulo, Brazil. Biota Neotrop. 12(4): http://www.biotaneotropica.org.br/v12n4/en/abstract?article+bn00712042012

Abstract: The harvestmen fauna of the Floresta Nacional de Ipanema (FLONA Ipanema) and Parque Estadual Carlos Botelho (PE Carlos Botelho) were inventoried using nocturnal manual collection and sifting of litter. Fourteen species were recorded from the FLONA Ipanema, a richness and diversity higher than those previously reported for other localities in Atlantic Semi-deciduous Forest. The PE Carlos Botelho, with 38 recorded species, is the third richest site for harvestmen in the state of São Paulo. The estimates of species richness place the FLONA Ipanema with a richness of locations near the Coastal Atlantic Rain Forest. A similarity analysis showed that the areas possess only a few species in common, indicated by the very low of similarities indexes, showing the high level of endemism of harvestmen species. The similarities in harvestmen composition were related to the distance between the areas. PE Carlos Botelho showed high similarity with the Parque da Onça Parda (only $5 \mathrm{~km}$ away) and with other areas of Coastal Atlantic Rain Forest. The FLONA Ipanema showed low similarity indexes with the other areas analyzed. In a DCA analysis, PE Carlos Botelho forms a group with other areas of Coastal Atlantic Rain Forest and FLONA Ipanema is placed in an intermediate position between the areas of Coastal Atlantic Rain Forest and areas of Atlantic Semi-deciduous Forest and Cerrado.

Keywords: diversity, Atlantic Semi-deciduous Forest, Coastal Atlantic Rain Forest, conservation units.

RESENDE, L.P.A., PINTO-DA-ROCHA, R. \& BRAGAGNOLO, C. A fauna de opiliões (Arachnida: Opiliones) do Parque Estadual Carlos Botelho e Floresta Nacional de Ipanema, São Paulo, Brazil. Biota Neotrop. 12(4): http://www.biotaneotropica.org.br/v12n4/pt/abstract?article+bn00712042012

Resumo: A fauna de opiliões da Floresta Nacional de Ipanema (FLONA Ipanema) e Parque Estadual Carlos Botelho (PE Carlos Botelho) foi inventariada através de coleta manual noturna e triagem de folhiço com peneira. Catorze espécies foram registradas na FLONA Ipanema, a maior riqueza conhecida para áreas de Floresta Atlântica Semidecídua. O PE Carlos Botelho teve 38 espécies registradas, sendo a terceira área mais rica em opiliões no estado de São Paulo. As estimativas de riqueza de espécies colocam a FLONA Ipanema próxima do observado nas localidades de Floresta Atlântica Ombrófila. Uma análise de similaridade mostrou que as diferentes áreas de Mata Atlântica possuem poucas espécies em comum, indicado pelos baixos índices de similaridade, o que demonstra o alto grau de endemismo das espécies de opiliões. A similaridade entre as faunas de opiliões foi relacionada com a distância geográfica entre as áreas. PE Carlos Botelho apresentou alta similaridade com o Parque da Onça Parda (distantes somente 5 quilômetros) e com outras áreas de Mata Atlântica Ombrófila. A FLONA Ipanema apresentou baixos índices de similaridade com as demais áreas analisadas. Na análise de DCA, o PE Carlos Botelho formou um grupo com as demais áreas da Mata Atlântica Ombrófila e a FLONA Ipanema apresentou uma posição intermediária entre as áreas de Mata Atlântica Ombrófila e as de Floresta Atlântica Semidecídua e Cerrado.

Palavras-chave: diversidade, Floresta Atlântica Semidecídua, Floresta Atlântica Ombrófila, unidades de conservação. 


\section{Introduction}

The Atlantic Rain Forest extends over almost the entire Brazilian coast, in a wide latitudinal range $\left(6-30^{\circ} \mathrm{S}\right)$, and is divided into two major physiognomic units. The Coastal Atlantic Rain Forest, rises to over 1,000 meters above sea level and features a warm and humid climate, with no marked seasonality. The Atlantic Semi-deciduous Forest spreads inland, away from the coast, with elevations that can exceed 600 meters and seasonal climate, with well marked dry and rainy seasons (Oliveira-Filho \& Fontes 2000). Originally this biome covered 1.1 million $\mathrm{km}^{2}$ of the country, but currently there are only isolated fragments of different sizes that comprise less than $7.6 \%$ of the original cover (Morellato \& Haddad 2000), and are still under great pressure from human activities.

The order Opiliones, with approximately 6,500 described species (Kury 2011), are especially diverse in the Atlantic Rain Forest, with more than 600 described species, of which approximately $97.5 \%$ are found exclusively in this biome (Pinto-da-Rocha et al. 2005) The order is divided into four suborders (Cyphophthalmi, Dyspnoi, Eupnoi and Laniatores), with Laniatores being the most diverse group, with over 4,100 described species worldwide (Kury 2011). Gonyleptidae is the largest family of Laniatores and one of the most diverse groups of the order Opiliones, with more than 823 described species (Kury 2003). The family is endemic from Neotropics and Pinto-da-Rocha et al. (2005), based on the geographical distribution of four subfamilies of Gonyleptidae restricted to Atlantic Rain Forest, divided the biome in 12 areas of endemism. The Atlantic Forest in São Paulo covers two of these areas, the Serra do Mar of São Paulo (SMSP) and the South of São Paulo (SSP), both representing the richest regions in the world for harvestmen, with approximately 220 recorded species (Kury 2003).

Historically, the harvestmen fauna of the state of São Paulo was studied by faunistic surveys conducted on the islands of the coast, such as Alcatrazes (Mello-Leitão 1923), São Sebastião (Luederwaldt 1929), Búzios and Vitoria (Soares 1966), the caves in the Ribeira Valley (Trajano \& Gnaspini-Netto 1991, Pinto-da-Rocha 1994), the biological stations of Alto da Serra de Paranapiacaba (Giltay
1928, Soares 1944a, Bragagnolo \& Pinto-da-Rocha 2009), and Boracéia (Soares 1942, 1944b). Recent studies were carried out, using standardized collecting protocols, in several areas during the project "Biodiversity of Arachnida and Myriapoda of São Paulo", between 2000 and 2004. Other areas were inventoried later, such as the Estação Ecológica Juréia-Itatins (Brescovit et al. 2004), Reserva Morro Grande (Bragagnolo et al. 2007) and Reserva Particular do Patrimônio Natural da Onça Parda (Resende et al. 2012).

The Parque Estadual Carlos Botelho (PE Carlos Botelho) is an important remnant of Atlantic Rain Forest with $376 \mathrm{~km}^{2}$ completely covered by primary Coastal Atlantic rain Forest. The Floresta Nacional de Ipanema (FLONA Ipanema) is covered by Atlantic Semideciduous Forest, more fragmented and impacted by human action. The two areas represent important preservation areas and faunal inventories are essential for implementing effective management plans. The present study aimed to survey the harvestmen fauna of these two areas, to expand the knowledge on the geographical distribution of the group and better understand the distribution of harvestmen communities in different vegetation types.

\section{Materials and Methods}

\section{Study areas}

The PE Carlos Botelho (see Figure 1) is a unit of integral protection. It is located between latitudes $24^{\circ} 06^{\prime}$ and $24^{\circ} 14^{\prime} \mathrm{S}$ and longitudes $47^{\circ} 47^{\prime}$ and $48^{\circ} 07^{\prime} \mathrm{W}$. It covers an area of 37,644 ha, belonging to four municipalities: São Miguel Arcanjo, Sete Barras, Capão Bonito and Tapiraí. The park is mainly covered by primary Coastal Atlantic Rain Forest. The region has high temperatures and well defined rain in the Summer months, alternating with periods of lower rainfall in Winter. Average rainfall varies from 1,700 to $2,400 \mathrm{~mm}$ and average temperatures from 17 to $22{ }^{\circ} \mathrm{C}$ (Ab'Saber 1970, 1973).

The FLONA Ipanema (see Figure 2) is a conservation reserve of sustainable use. It is located between latitudes $23^{\circ} 25^{\prime}$ and $23^{\circ} 28^{\prime} \mathrm{S}$ and longitudes $47^{\circ} 33^{\prime}$ and $47^{\circ} 40^{\prime} \mathrm{W}$. It covers an area of 5,180 ha,

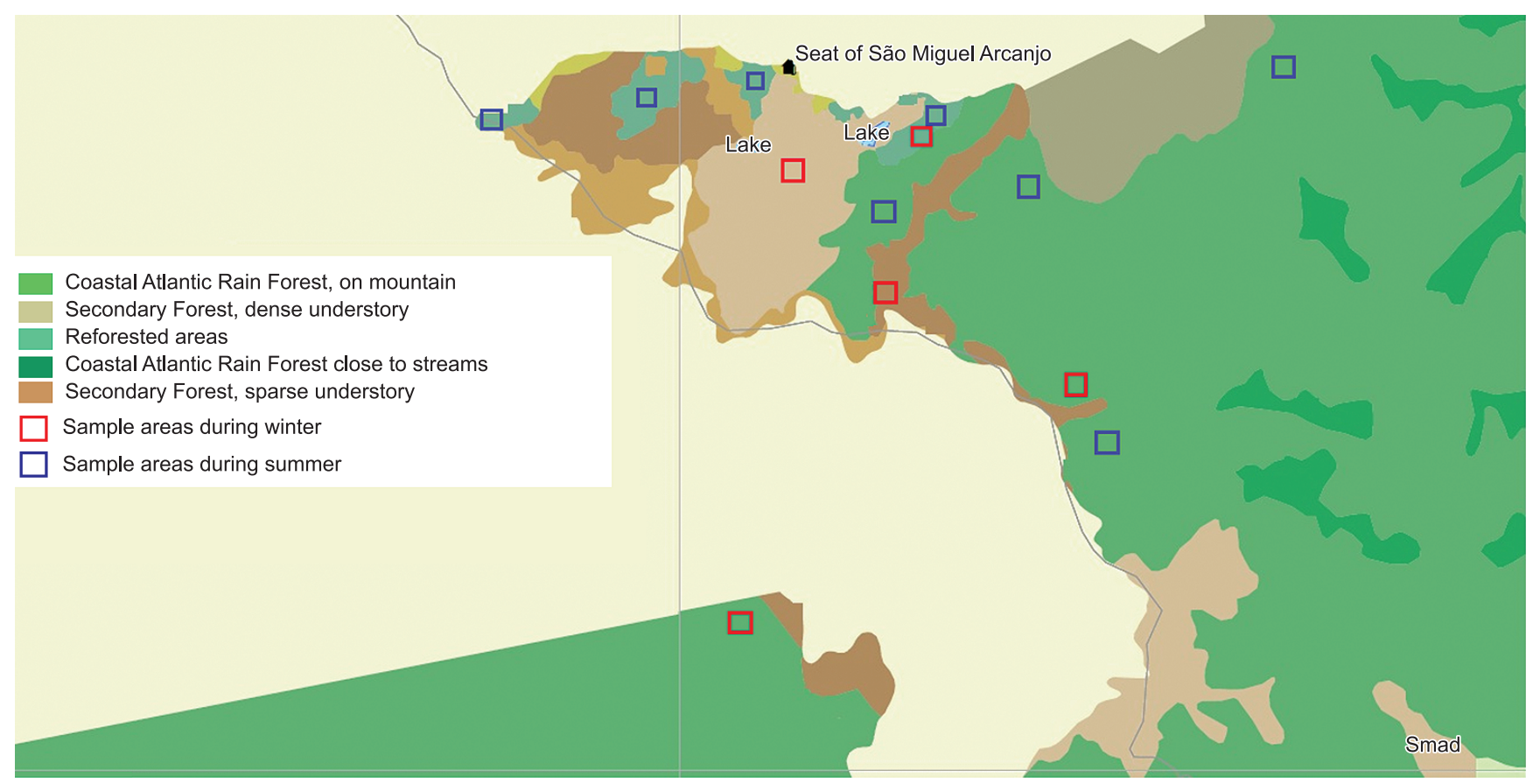

Fonte: Bases Cartográficas Digitais IBGE e Instituto Florestal Edição: Instituto Ekos Brasil Elaboração: Giorgia Limnios

Figure 1. Sampled sites in the Parque Estadual Carlos Botelho, São Paulo, Brazil. 


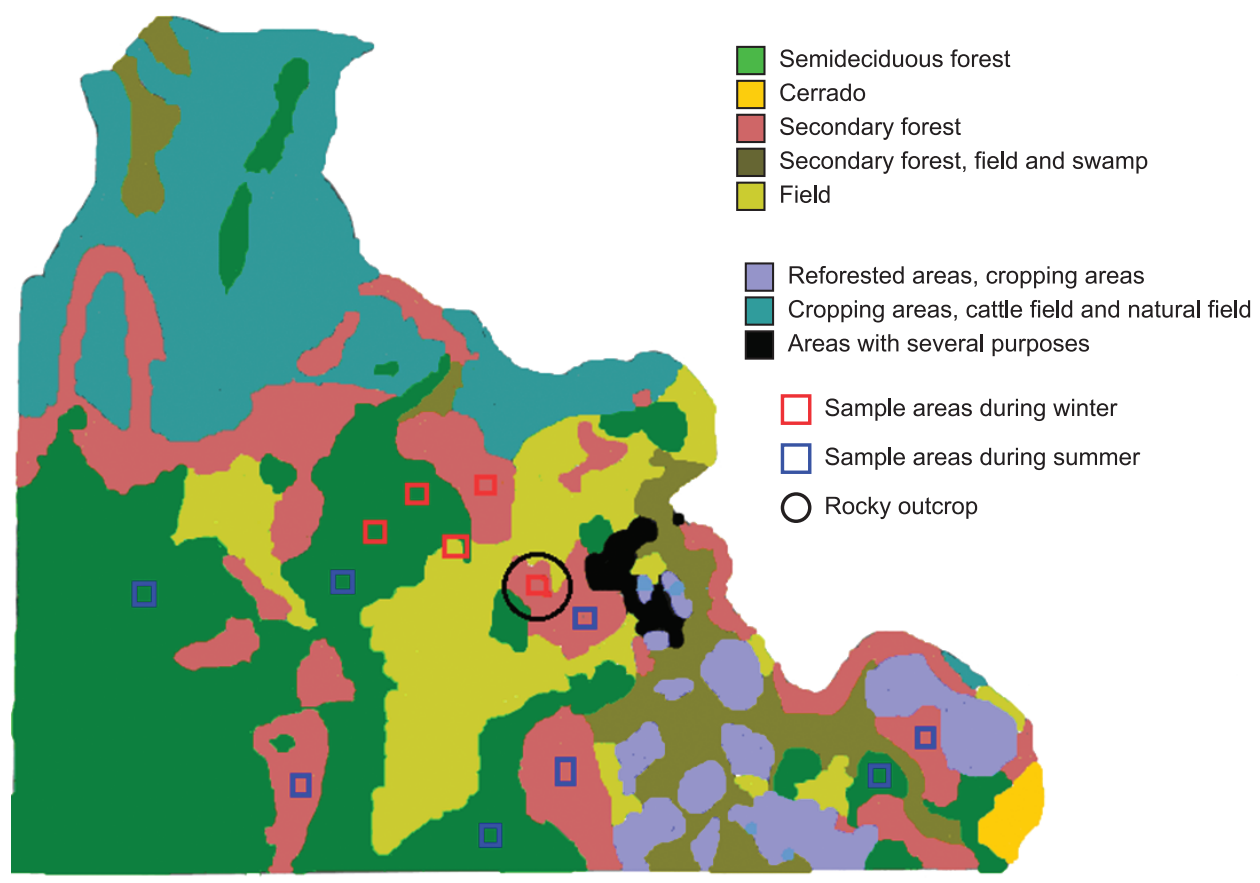

Fonte: Fávero, et al. 2002

Figure 2. Sampled sites in the Floresta Nacional de Ipanema, São Paulo, Brazil.

belonging to three counties: Iperó, Capela do Alto and Araçoiaba da Serra. According to Fávero (2001), the area of the FLONA Ipanema is covered by fragments of forest vegetation in intermediate and advanced state of regeneration, canopy estimated at $20 \mathrm{~m}$. Vegetation of the area includes Atlantic Semi-deciduous Forest and riparian vegetation, cerrado (savannah) areas, capoeiras in early stages of regeneration and fields dominated by grasses and herbs. The park also includes areas of swamps and bogs, plantations of Eucalyptus and Pinus and multiple use areas, with livestock, agriculture and human settlements. There is a significant human influence (the large city of Sorocaba is only $25 \mathrm{~km}$ away, and houses are within the buffer zone). The climate shows a more pronounced seasonality, with periods of more intense precipitation in the Summer and a marked dry season in Winter (Albuquerque \& Rodrigues 2000). During the dry season an important environmental factor that acts in the area of the FLONA Ipanema is the fire (natural and/or induced), that occurs almost every year (Fávero 2001).

\section{Sampling}

Two field trips were made to each park (18 to 22 July 2011 and 09 to 13 January 2012 at FLONA Ipanema and 25 to 29 July 2011 and 17 to20 January 2012 in PE Carlos Botelho). In July, five environments were sampled in each park. In the FLONA Ipanema, samplings were conducted in areas of riparian forest, secondary forest, forest-field ecotone, scrub vegetation and rocky outcrops, while in the PE Carlos Botelho samplings were carried out in areas of alluvial dense rain forest, reforestation, dense montane rain forest, and secondary forest with different degree of understory density. In each of the five environments, a sampling of four hours (from 18:00 to 22:00 pm) was conducted in 16 points. At each of these points, a transect $(10 \mathrm{~m} \times 30 \mathrm{~m}, 10 \mathrm{~m}$ apart from each other) was sampled by one collector. At each transect, harvestmen were collected in litter, leaves and stems to a height of one meter, and fixed in $70 \%$ ethanol. At the margin of each transect a square meter of litter was collected for subsequent screening and collection of harvestmen.

In January, samplings were conducted in two environments in each park (capoeira and secondary forest in FLONA Ipanema and reforestation and dense montane rain forest in PE Carlos Botelho). In each area, four independent sampling points, with a distance of at least $200 \mathrm{~m}$ between them, were selected,. At each of these points, sampling was carried out along eight transects $(10 \mathrm{~m} \times 30 \mathrm{~m}, 10 \mathrm{~m}$ apart from each other) sampled by four collectors in two hours of active night searching (four transects from 19:00 to 21:00 and four transects from 22:00 to 0:00 pm), totalizing eight subsamples per area. Four square meters of litter were removed around each area for subsequent sampling of harvestmen in winkler sifting.

Temperature and humidity were measured just before beginning each subsample in two sampling seasons. The material collected was deposited in the Museu de Zoologia da Universidade de São Paulo (MZUSP, curator: Ricardo Pinto-da-Rocha).

\section{Statistic analysis}

To determine the alpha diversity of harvestmen, the effective number of species (value representing the number of species in a given community with all the species present in equal abundance) was used, using the formula: $\exp \left(\sum\right.$ pi In pi) (Jost 2006), which is the same as $\exp \left(\mathbf{H}^{\prime}\right)$ where $\exp$ is the natural $\log \ln$ raised to power $\mathbf{H}^{\prime}$, and $\mathbf{H}^{\prime}$ is the Shannon index $\left(\mathbf{H}^{\prime}=\sum \mathbf{p i} \mathbf{l n} \mathbf{p i}\right)$, where pi is the proportion of species in relation to the total number of individuals in the community and $\mathbf{I n}$ is the neperian $\log (\approx 2,72)$ (Magurran 1988). To calculate the beta diversity, a similarity analysis, using the Jaccard index $(\mathbf{S}=\mathbf{a} /(\mathbf{a}+\mathbf{b}+\mathbf{c})$ ) (Magurran 1988, Table 3), and a detrend correspondent analysis (DCA), between 22 sites in the State of São Paulo based on occurrence of species from Bragagnolo (2005), Pinto-da-Rocha et al. (2005) and Resende et al. (2012), were used. A Mantel test was performed to analyze the correlation between the similarity (Jaccard) and geographic distance (Euclidian) matrices. The analyses were conducted using computer program PAST - Paleontological Statistic (Hamer et al. 2001). The species richness was estimated with Jackknife 1, Jackknife 2, Chao 1 and Chao 2 for both parks using computer program EstimateS 8.2.0 (Colwell 2006), which also produced species accumulation curves with data randomized 200 times. 


\section{Results}

\section{Environmental parameters}

In Winter, the average temperature at FLONA Ipanema was $16.4{ }^{\circ} \mathrm{C}(\mathrm{SD}=2.321)$ and the average relative humidity $66.2 \%$ $(\mathrm{SD}=6.976)$. In Summer, the average temperature was $21.1{ }^{\circ} \mathrm{C}$ $(\mathrm{SD}=1.635)$ and relative humidity $69.9 \%(\mathrm{SD}=7.099)$. In PE Carlos Botelho, average temperatures were $16.3^{\circ} \mathrm{C}(\mathrm{SD}=1.505)$ in Winter and $20.1^{\circ} \mathrm{C}(\mathrm{SD}=1.739)$ in Summer, and average relative humidity was $69 \%(\mathrm{SD}=6.486)$ in Winter and $85 \%(\mathrm{SD}=5.151)$ in Summer.

The data shows that the average temperatures at both locations are very similar, in contrast to the mean relative humidity, which is much higher in PE Carlos Botelho.

\section{Richness and abundance}

A total of 387 harvestmen were collected in FLONA Ipanema (171 in Winter and 200 in Summer, with manual collection, and 15 in Winter and one in Summer sifting leaf litter) representing 14 species (Table 1). Two species were dominant, Mischonyx squalidus Bertkau (91 specimens) and Discocyrtus sp.1 (88 specimens), both corresponding to $46.25 \%$ of the total abundance (Figure 3 ). The species accumulation curve (Figure 5) showed a tendency towards stability, with $80 \%$ of the observed richness obtained before $40 \%$ of individuals had been added. Although the diversity estimates were

Table 1. Harvestmen of the Floresta Nacional de Ipanema, collected with two methos in two seasons (Winter, July 2011 and Summer January 2012) Captions: Man. Col: Manual Collection; Lf: Leaflitter.

\begin{tabular}{|c|c|c|c|c|c|}
\hline \multirow{2}{*}{ Species } & \multicolumn{2}{|c|}{ July-11 } & \multicolumn{2}{|c|}{ Jan.-12 } & \multirow{2}{*}{ Total } \\
\hline & M.C & Lf. & M.C & Lf. & \\
\hline \multicolumn{6}{|l|}{ Gonyleptidae } \\
\hline \multicolumn{6}{|l|}{ Gonyleptinae } \\
\hline Acanthogonyleptes sp & 0 & 0 & 2 & 0 & 2 \\
\hline Mischonyx squalidus Bertkau, 1880 & 34 & 0 & 57 & 0 & 91 \\
\hline Mischonyx sp1 & 0 & 0 & 25 & 0 & 25 \\
\hline \multicolumn{6}{|l|}{ Goniosomatinae } \\
\hline Acutisoma longipes Roewer, 1913 & 17 & 0 & 0 & 0 & 17 \\
\hline \multicolumn{6}{|l|}{ Mitobatinae } \\
\hline Promitobates ornatus (Mello-Leitão, 1922) & 39 & 0 & 0 & 0 & 39 \\
\hline Longiperna cancellata (Roewer, 1913) & 1 & 0 & 0 & 0 & 1 \\
\hline Promitobates intermedius (Mello-Leitão, 1935) & 0 & 0 & 19 & 0 & 19 \\
\hline Promitobates trapista Bragagnolo \& Pinto-da-Rocha, 2012 & 1 & 0 & 0 & 0 & 1 \\
\hline \multicolumn{6}{|l|}{ Pachylinae } \\
\hline Discocyrtus invalidus Piza, 1938 & 10 & 0 & 35 & 0 & 45 \\
\hline Discocyrtus sp1 & 69 & 0 & 19 & 0 & 88 \\
\hline Discocyrtus $\mathrm{sp} 2$ & 0 & 0 & 15 & 0 & 15 \\
\hline Parapachyloides armatus (Mello-Leitão, 1931) & 0 & 0 & 27 & 0 & 27 \\
\hline Pucrolia $\mathrm{sp}$ & 0 & 15 & 0 & 0 & 15 \\
\hline \multicolumn{6}{|l|}{ Tricommatinae } \\
\hline \multirow[t]{2}{*}{ Pseudopachylus longipes Roewer, 1912} & 0 & 0 & 1 & 1 & 2 \\
\hline & 171 & 15 & 200 & 1 & 387 \\
\hline
\end{tabular}

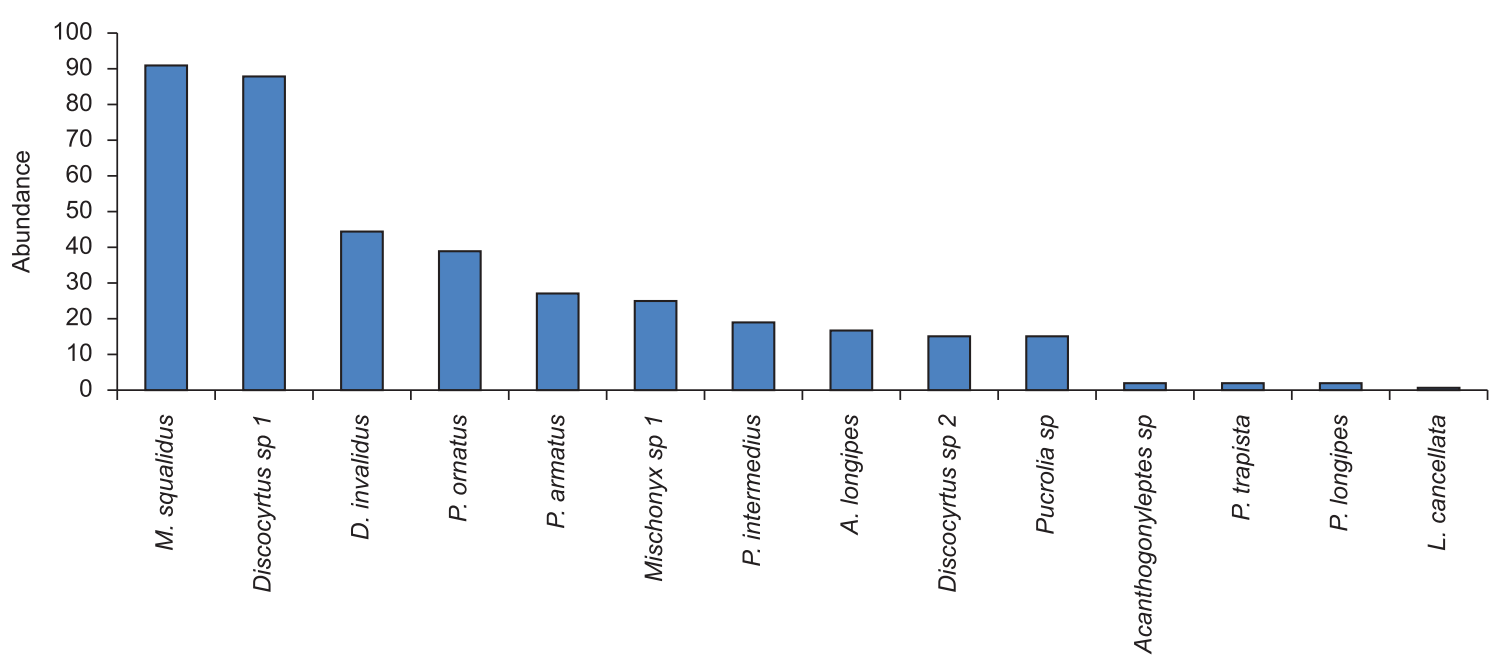

Figure 3. Distribution of harvestmen species abundance in Floresta Nacional de Ipanema, Iperó, São Paulo, Brazil. 
very similar, Chao 1 and Chao 2 had the lowest, approximately 16 species. Jackknife 1 showed an average estimate of 17 species, and Jakknife 2 showed the highest with 19 species.

In PE Carlos Botelho, 1763 individuals were collected (594 in Winter and 1,091 in Summer with manual collecting and 36 in Winter and 42 in Summer sifting leaf litter) representing 38 species, 36 of which belong to Laniatores and two to Eupnoi (Table 2). The dominant species were Holcobunus nigripalpis Roewer (445 specimens), Neosadocus maximus (Giltay) (296 specimens) and Munequita sp. (261 specimens), corresponding to $56.83 \%$ of the total abundance (Figure 4). The species accumulation curve (Figure 6) showed a tendency to stabilize, with $80 \%$ of the richness obtained by addition of approximately $30 \%$ of the specimens. The behavior of the estimators (Figure 6) was similar to that observed for the FLONA Ipanema, with Chao 1 and 2 showing the lowest values (40 species), Jackknife an intermediate value (43 species) and Jackknife 2 the highest (44 species).

Manual collecting was responsible for most of the observed abundance and also for most of the richness found in both parks. In
FLONA Ipanema, manual collecting yielded 13 of the 14 collected species. Only Pucrolia sp. was obtained exclusively by sifting litter. In PE Carlos Botelho the manual collecting was responsible for 36 of the 38 collected species. The sorting of litter added to the list the species Pucrolia sp.and Tricommatinae gen.nov.

\section{Alfa and beta diversity}

The alpha diversity, measured by the effective number of species was 8.61 for the FLONA Ipanema and 11.634 for the PE Carlos Botelho. The table of similarity showed the areas possess only a few species in common, generating very low indices of similarities (Table 3). Similarity indexes higher than 0.5 were found only between sites extremely close together (PE Carlos Botelho and Onça Parda $-5 \mathrm{~km}$, Morro Grande and Miracatu $-70 \mathrm{~km}$ or Porto Cabral and Morro do Diabo - $40 \mathrm{~km})$. The Mantel test indicated that the similarities of harvestmen fauna between areas were correlated to the geographical distances between them $(r=0.407 ; \mathrm{p}<0.0001)$. FLONA Ipanema showed low similarity indexes with the other areas

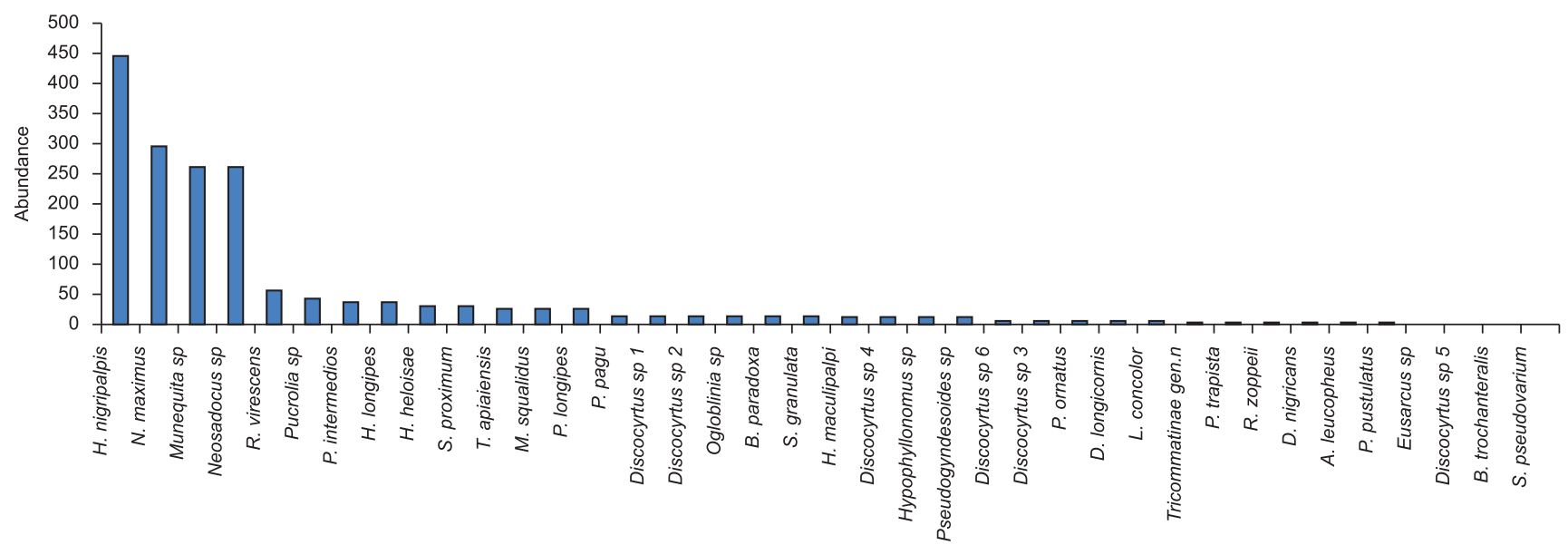

Figure 4. Distribution of harvestmen species abundance in Parque Estadual Carlos Botelho, São Miguel Arcanjo, São Paulo, Brazil.

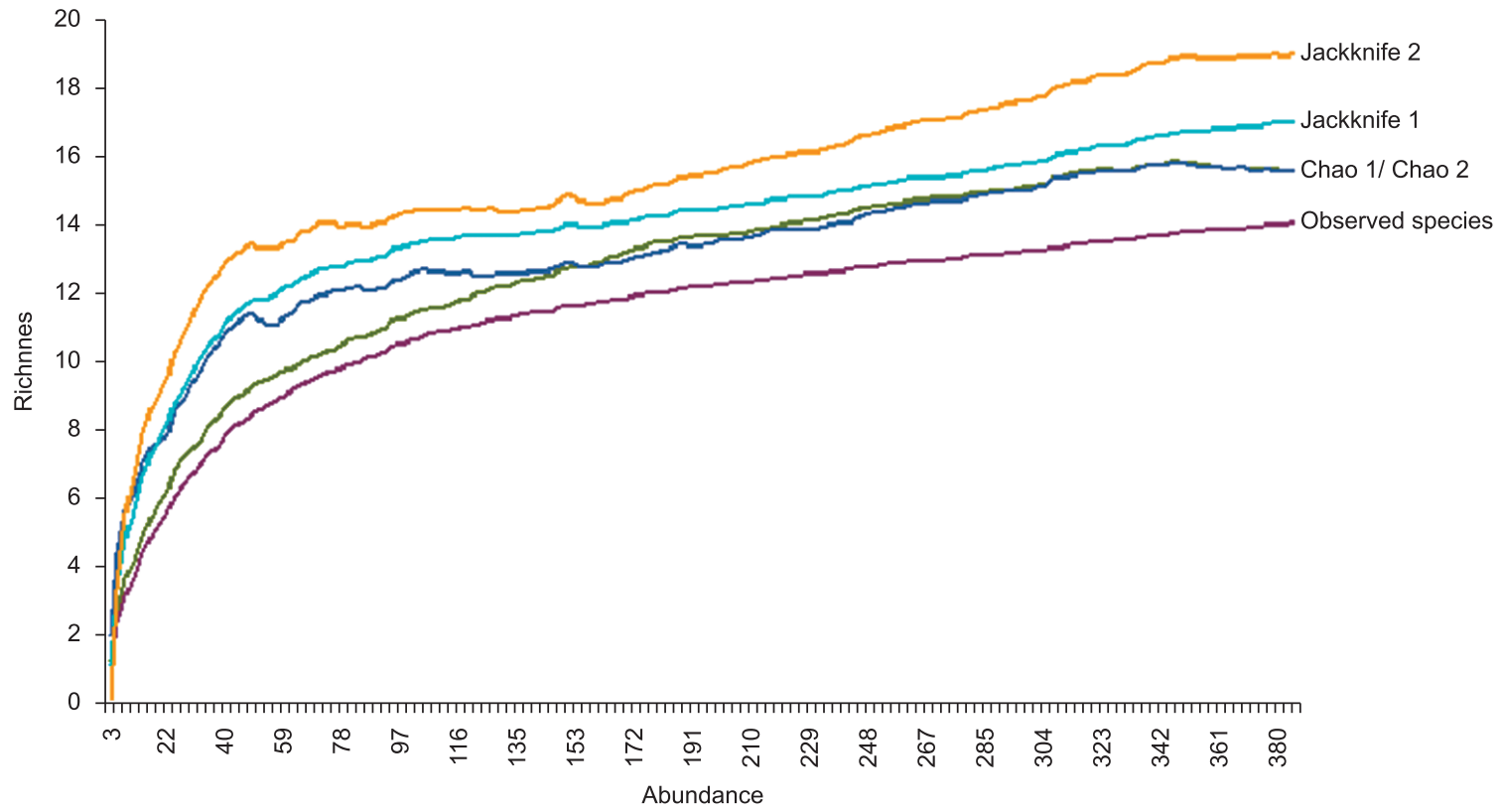

Figure 5. Accumulation curve and estimates for harvestmen species for Floresta Nacional de Ipanema, Iperó, São Paulo, Brazil. 
Table 2. Harvestmen of the Parque Estadual Carlos Botelho, collected with two methos in two seasons (Winter, July 2011 and Summer January 2012) Captions: Man. Col: Manual Collection; Lf: Leaflitter.

\begin{tabular}{|c|c|c|c|c|c|}
\hline \multirow{2}{*}{ Species } & \multicolumn{2}{|c|}{ Jul-11 } & \multicolumn{2}{|c|}{ Jan-12 } & \multirow{2}{*}{ Total } \\
\hline & M.C & Lf. & M.C & Lf. & \\
\hline \multicolumn{6}{|l|}{ Gonyleptidae } \\
\hline \multicolumn{6}{|l|}{ Bourguyiinae } \\
\hline Bourguyia trochanteralis (Roewer, 1930) & 1 & 0 & 0 & 0 & 1 \\
\hline \multicolumn{6}{|l|}{ Caelopyginae } \\
\hline Ampheres leucopheus (Mello-Leitão, 1922) & 2 & 0 & 0 & 0 & 2 \\
\hline Pristocnemis pustulatus Kollar in Koch, 1839 & 2 & 0 & 0 & 0 & 2 \\
\hline \multicolumn{6}{|l|}{ Goniosomatinae } \\
\hline Serracutisoma proximum (Mello-Leitão, 1922) & 29 & 0 & 1 & 0 & 30 \\
\hline Serracutisoma pseudovarium Da-Silva \& Gnaspini, 2010 & 1 & 0 & 0 & 0 & 1 \\
\hline \multicolumn{6}{|l|}{ Gonyleptinae } \\
\hline Neosadocus maximus (Giltay, 1928) & 296 & 0 & 0 & 0 & 296 \\
\hline Neosadocus sp & 0 & 0 & 261 & 0 & 261 \\
\hline Mischonyx squalidus Bertkau, 1880 & 0 & 0 & 27 & 0 & 27 \\
\hline \multicolumn{6}{|l|}{ Hernandariinae } \\
\hline Hernandaria heloisae (H. Soares, 1945) & 6 & 0 & 24 & 1 & 31 \\
\hline Pseudotrogulus pagu DaSilva \& Pinto-da-Rocha, 2010 & 9 & 1 & 4 & 2 & 16 \\
\hline \multicolumn{6}{|l|}{ Mitobatinae } \\
\hline Discocyrtoides nigricans (Mello-Leitão, 1922) & 3 & 0 & 0 & 0 & 3 \\
\hline Longiperna concolor (Mello-Leitão, 1923) & 5 & 0 & 0 & 0 & 5 \\
\hline Promitobates intermedius (Melo-Leitão, 1935) & 36 & 0 & 0 & 0 & 36 \\
\hline Promitobates ornatus (Mello-Leitão, 1922) & 2 & 0 & 4 & 0 & 6 \\
\hline Promitobates trapista Bragagnolo \& Pinto-da-Rocha, 2012 & 1 & 0 & 3 & 0 & 4 \\
\hline \multicolumn{6}{|l|}{ Pachylinae } \\
\hline Discocyrtus longicornis (Mello-Leitão, 1922) & 2 & 0 & 4 & 0 & 6 \\
\hline Discocyrtus sp1 & 15 & 0 & 1 & 0 & 16 \\
\hline Discocyrtus sp2 & 12 & 0 & 3 & 0 & 15 \\
\hline Discocyrtus sp3 & 6 & 0 & 0 & 0 & 6 \\
\hline Discocyrtus sp4 & 7 & 0 & 4 & 0 & 11 \\
\hline Discocyrtus sp5 & 1 & 0 & 0 & 0 & 1 \\
\hline Discocyrtus sp6 & 7 & 0 & 0 & 0 & 7 \\
\hline Eusarcus sp & 0 & 0 & 1 & 0 & 1 \\
\hline Hypophyllonomus longipes Giltay, 1928 & 8 & 0 & 26 & 1 & 35 \\
\hline Hypophyllonomus maculipalpi (Piza, 1938) & 0 & 0 & 12 & 0 & 12 \\
\hline Hypophyllonomus sp & 0 & 0 & 6 & 5 & 11 \\
\hline Ogloblinia $\mathrm{sp}$ & 12 & 3 & 0 & 0 & 15 \\
\hline Pseudogyndesoides sp & 6 & 5 & 0 & 0 & 11 \\
\hline Pucrolia sp & 0 & 18 & 0 & 23 & 41 \\
\hline Rhioxyna zoppeii (Soares, 1948) & 1 & 0 & 2 & 0 & 3 \\
\hline Roeweria virescens (Mello-Leitão, 1940) & 50 & 0 & 8 & 0 & 58 \\
\hline Triglochinura apiaiensis (Soares \& Bauab-Vianna, 1972) & 3 & 1 & 21 & 3 & 28 \\
\hline \multicolumn{6}{|l|}{ Sodreaninae } \\
\hline Sodreana granulata (Mello-Leitão, 1937) & 8 & 0 & 6 & 0 & 14 \\
\hline \multicolumn{6}{|l|}{ Tricommatinae } \\
\hline Bissula paradoxa Roewer, 1929 & 7 & 7 & 1 & 0 & 15 \\
\hline Pseudopachylus longipes Roewer, 1912 & 9 & 0 & 13 & 4 & 26 \\
\hline Tricommatinae gen.n & 0 & 1 & 0 & 3 & 4 \\
\hline \multicolumn{6}{|l|}{ Sclerosomatidae } \\
\hline \multicolumn{6}{|l|}{ Gagrellinae } \\
\hline Holcobunus nigripalpis Roewer, 1910 & 14 & 0 & 431 & 0 & 445 \\
\hline \multirow[t]{2}{*}{ Munequita sp } & 34 & 0 & 228 & 0 & 262 \\
\hline & 594 & 36 & 1091 & 42 & 1763 \\
\hline
\end{tabular}


analysed. The greater faunal similarity was with PE Carlos Botelho ( $\mathrm{Sj}=0.19$, only six species in common) followed by Porto Cabral ( $\mathrm{Sj}=0.17$, two species in common), and the Parque da Onça Parda (Onça Parda) $(\mathrm{Sj}=0.14$, four species in common). The PE Carlos Botelho showed a greater similarity to the Onça Parda $(\mathrm{Sj}=0.69)$, with the highest similarity index, and a high number of species in common (20 species). The PE Botelho also shows a high similarity with other localities of Serra do Paranapiacaba and other localities close by, with over 10 species in common (Alto do Ribeira $=0.3$; Miracatu $=0.31$; Paranapiacaba $=0.25$; Juréia-Itatins $=0.28$; Morro Grande $=0.29$ ). The DCA analysis shows results consistent with the similarity analysis, where the shaft has PE Carlos Botelho nested with other areas of Coastal Atlantic Rain Forest. FLONA Ipanema is placed in an intermediate position between the areas of Coastal Atlantic Rain Forest and areas of Atlantic Semi-deciduous Forest and Cerrado (Figure 7).

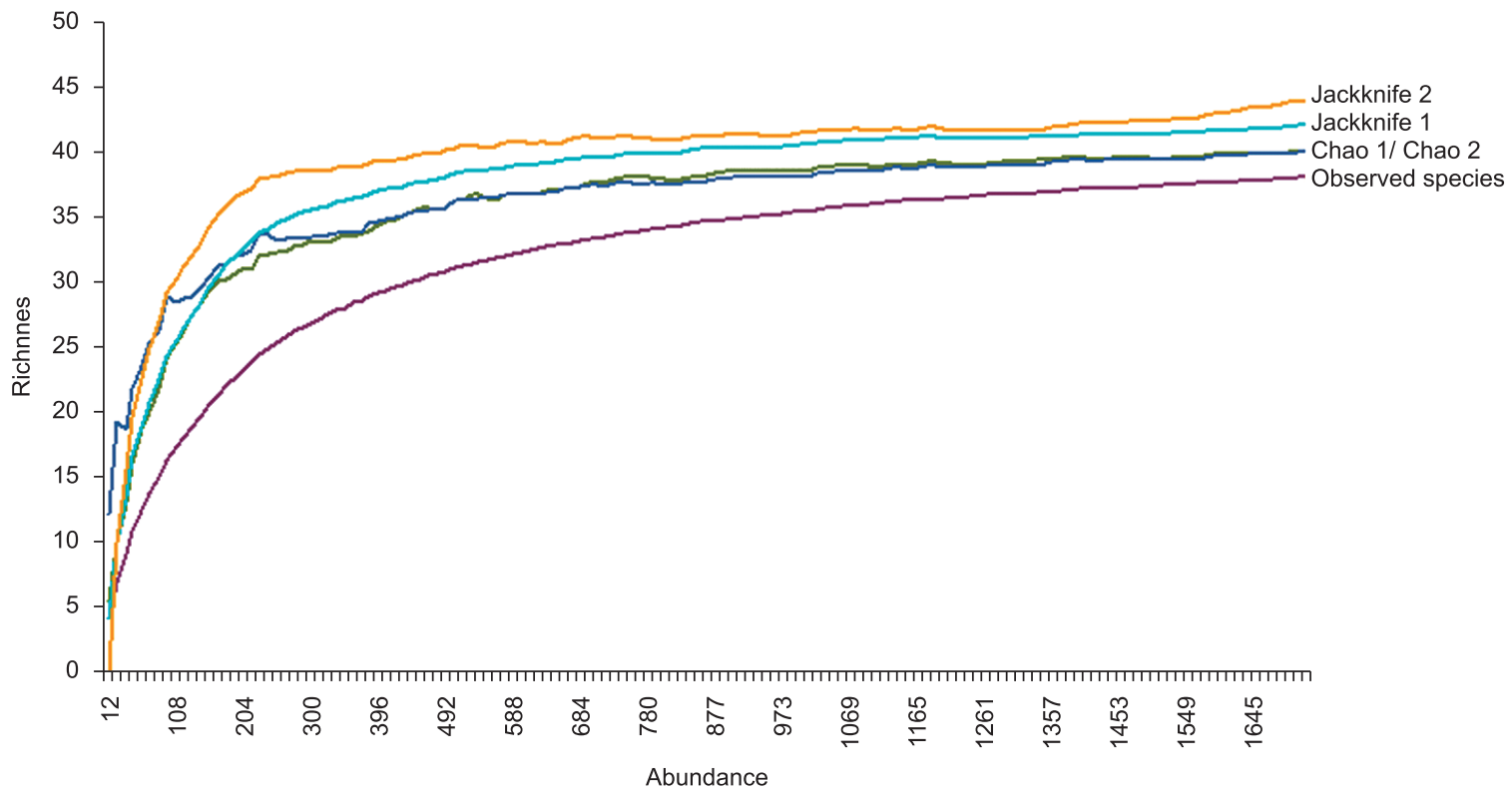

Figure 6. Accumulation curve and estimates for harvestmen species for PE Carlos Botelho, São Miguel Arcanjo, São Paulo, Brazil.

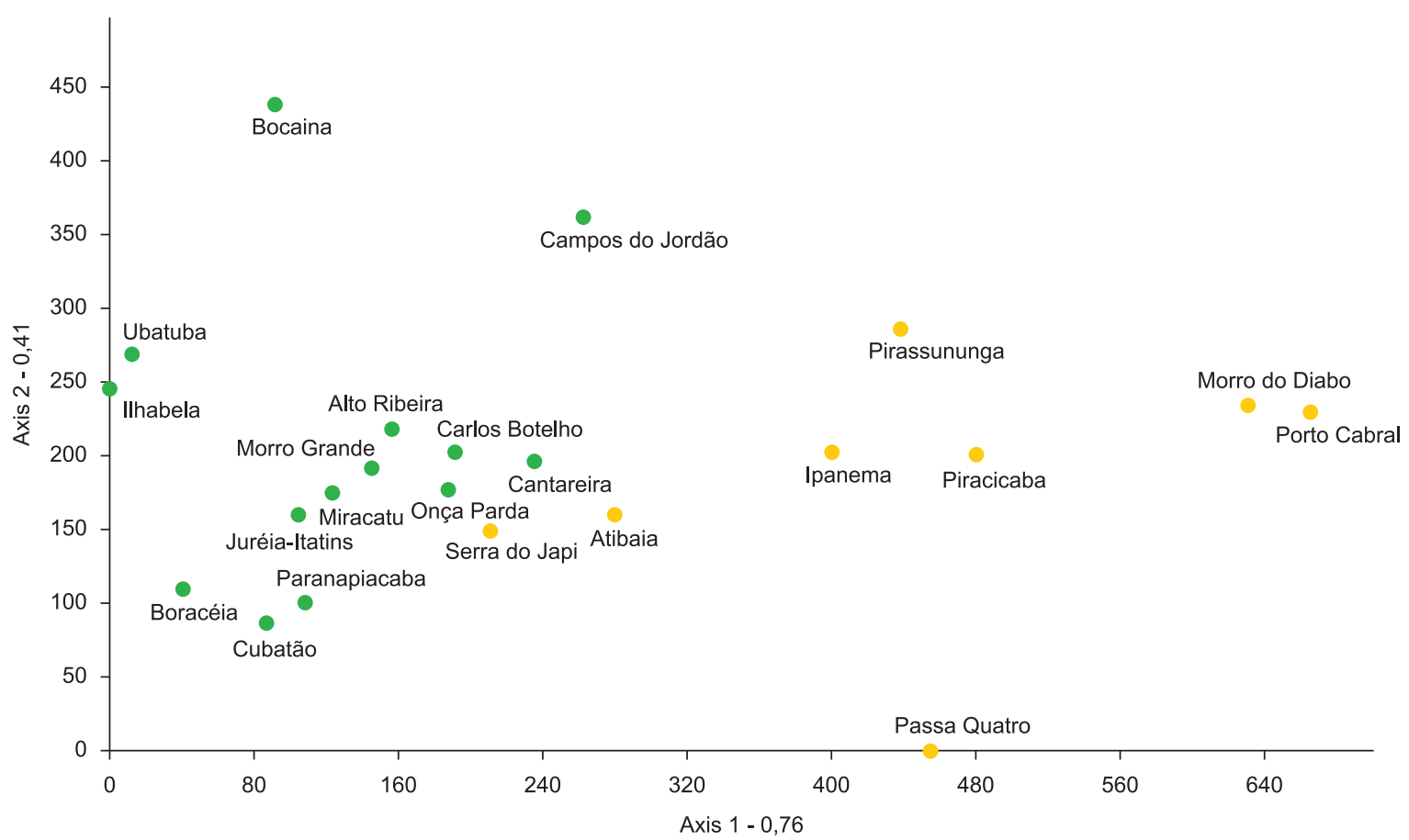

Figure 7. Biplot of axes 1 and 2 from a detrended correspondence analysis (DCA) on the presence of harvestman species in the 22 sites in São Paulo State, Brazil. Green circles represent Coastal Atlantic Rain Forest and yellow circles the Semi-deciduous and cerrado forests. 


\begin{tabular}{|c|c|}
\hline Ubatuba & 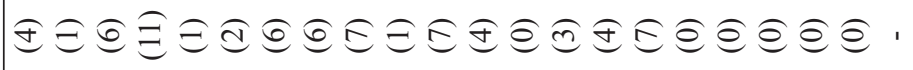 \\
\hline Serra do Japi & 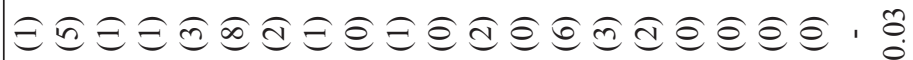 \\
\hline Porto Cabral & 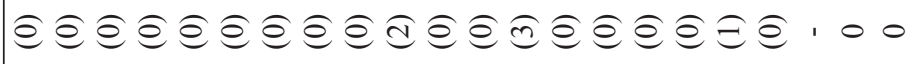 \\
\hline Pirassununga & 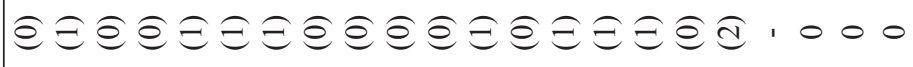 \\
\hline Piracicaba & 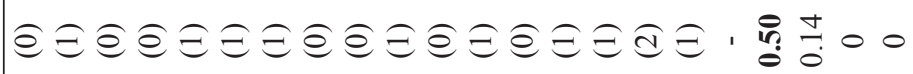 \\
\hline Passa Quatro & 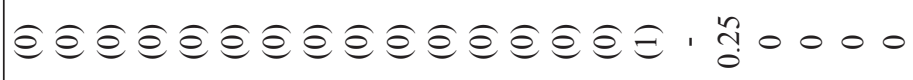 \\
\hline Paranapiacaba & 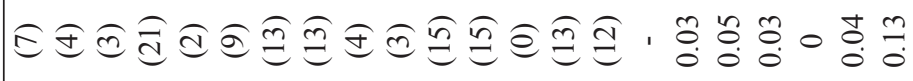 \\
\hline Onça Parda & 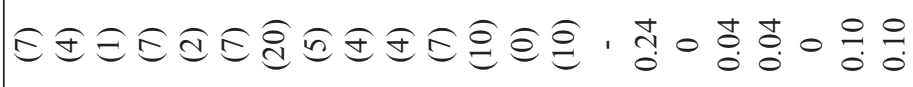 \\
\hline Morro Grande & 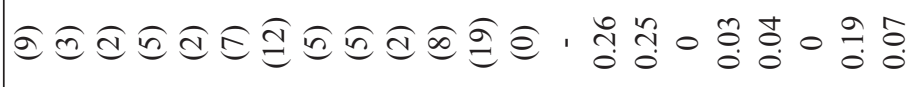 \\
\hline Morro do Diabo & 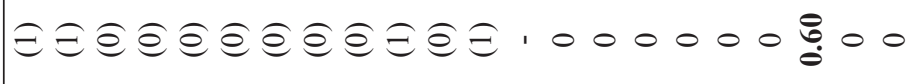 \\
\hline Miracatu & 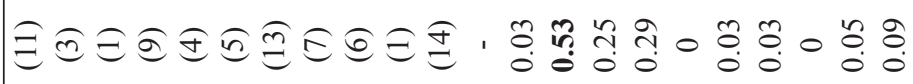 \\
\hline Juréia-Itatins & 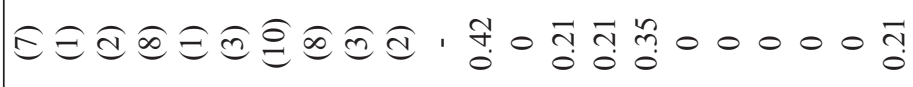 \\
\hline Ipanema & 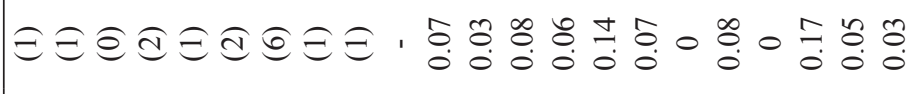 \\
\hline Ilhabela & 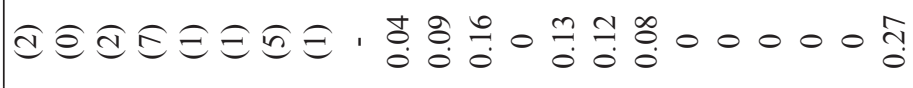 \\
\hline Cubatão & 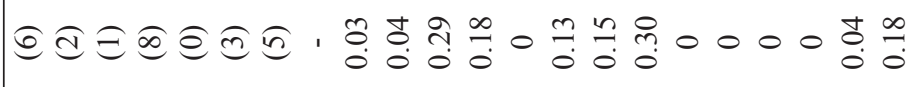 \\
\hline Carlos Botelho & 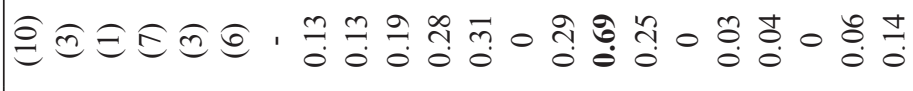 \\
\hline Cantareira & 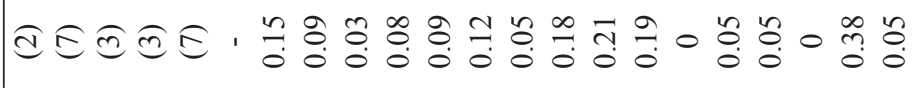 \\
\hline Campos do Jordão & 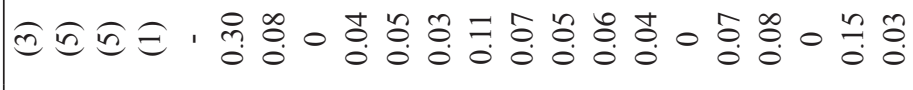 \\
\hline Boracéia & 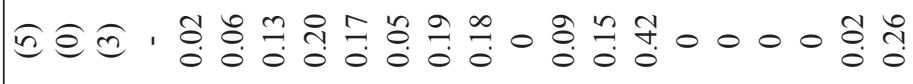 \\
\hline Bocaina & 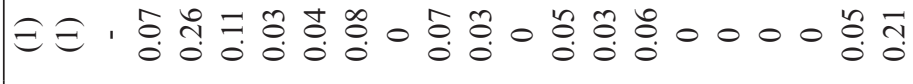 \\
\hline Atibaia & 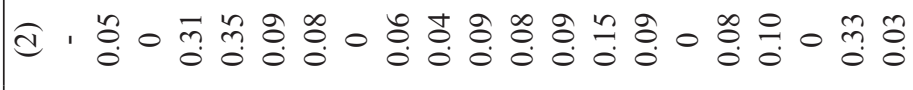 \\
\hline Alto Ribeira & 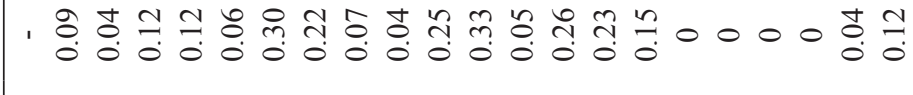 \\
\hline Richnnes & 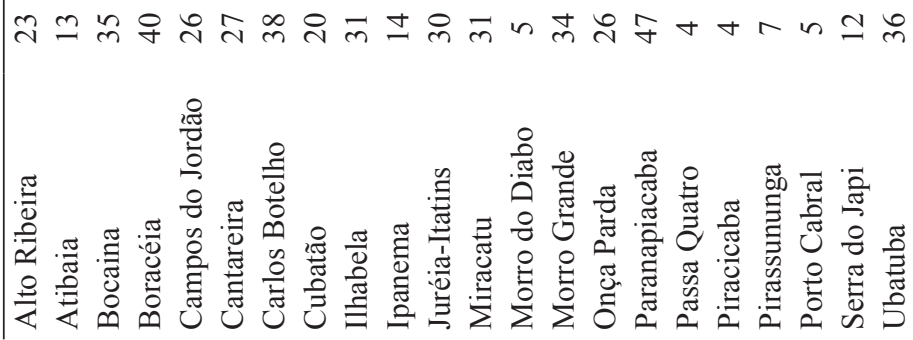 \\
\hline
\end{tabular}




\section{Discussion}

\section{Richness and abundance}

Data from this survey corroborate that obtained by Pinto-daRocha et al. (2005), since the PE Carlos Botelho was 2.7 times richer than FLONA Ipanema. The PE Carlos Botelho, with 38 recorded species, is the third richest locality in the state of São Paulo and stands as the sixth richest area in species of harvestmen of Brazil, surpassed only by the Parque Nacional da Serra dos Órgãos (64 species), Parque Nacional Itatiaia (48 species), Estação Biológica do Alto da Serra de Paranapiacaba (46 species), Petrópolis (45 species), and the Estação Biológica de Boracéia (39 species) (Pinto-da-Rocha et al. 2005). The comparison of the effective number of species of the PE Carlos Botelho with other areas of Coastal Atlantic Rain Forest previously analyzed by Resende et al. (2012) also places the park as an area of great diversity in the country (Resende et al. 2012).

The FLONA Ipanema, with 14 recorded harvestmen species, is the richest area of Atlantic Semi-deciduous Forest compared to other sites with the same vegetation type that have been inventoried (Porto Cabral with five, Serra do Japi with 11; Atibaia with 12 and Morro do Diabo with five species, see Pinto-da-Rocha et al. 2005). Besides the higher richness, the effective number of species of FLONA Ipanema was also higher than that of the Serra do Japi (effective number : 6.1, see Resende et al. 2012) and the Morro do Diabo (3.098).

The nonparametric estimators generated maximum estimates of 19 species of harvestmen for the FLONA Ipanema. This estimated richness is the highest for areas of Atlantic Semi-deciduous Forest and is close to some areas of Coastal Atlantic Rain Forest such as Parque Estadual de Ilhabela (21 spp); Parque Estadual Turístico Alto do Ribeira (PETAR) and Cubatão (both with 19 spp) (Bragagnolo 2005). It should be noted that such comparisons, even considering the higher estimates, only equaled the poorest regions in collected species (not estimated) of the Coastal Atlantic Rain Forest. Furthermore, these regions have not been extensively collected, such as the Parque Estadual de Ilhabela and PETAR, or suffered strong environmental degradation such as Cubatão.

Besides the differences between the richness, the expected pattern due to physiognomic differences in park area and quality between the two parks, the distribution patterns of species abundance of harvestmen were markedly different between the two areas (Figures 3 and 4). In FLONA Ipanema, Mischonyx squalidus was the dominat species, representing $23.6 \%$ of individuals collected, while the PE Carlos Botelho, this species represented only $1.5 \%$ of the total. Mischonyx is recognized a species of harvestmen associated to human disturbance in the environment (Mestre \& Pinto-da-Rocha 2004). The difference between the abundances of the species may reflect the environmental conditions of the parks. Moreover, in PE Carlos Botelho, there was a high dominance of Eupnoi $H$. nigripalpis, representing more than $25 \%$ of the collected individuals. According to Bragagnolo et al. (2007), the high dominance of few species of Eupnoi seems to be associated to human disturbance in the environment. This same pattern of dominance was recorded in Onça Parda (only $5 \mathrm{~km}$ from PE Carlos Botelho) by Resende et al. (2012). According Resende et al. (2012), the exploitation of wood for charcoal production in that region may have been responsible for the disturbances in that environment. Due to the close proximity between the areas, it is possible that the logging that occurred in the region of Onça Parda also reached the park area that was studied.

According to Pinto-da-Rocha et al. (2005), the Coastal Atlantic Rain Forest sites have a higher richness of harvestmen when compared to the locations of Atlantic Semi-deciduous Forest. One reason for this high diversity is that the Atlantic Coast receives the largest part of the moisture from the ocean, causing a rain shadow over the inland areas, which in turn end up getting only a third of the moisture (Behling \& Lichte 1997). Moreover, historically, Coastal Atlantic Rain Forest vegetation suffered events of expansion and retraction during glaciation, causing speciation in moments of isolation and increased diversity in times of expansion (Behling \& Lichte 1997). The vegetation of the Coastal Atlantic Rain Forest is also more diverse than that present in the interior regions and vegetation structure itself is more complex, creating a greater number of microhabitats and resources to be occupied (Oliveira-Filho \& Fontes 2000).

\section{Beta diversity}

The faunistic similarities respected the distance between sites, probably due to the low vagility of harvestmen and historical factors. However, natural barriers such as the Serra do Mar itself also provided a great influence on the isolation of these areas (Pinto-daRocha et al. 2005). High similarity indexes (greater than 0.5 ) were found only between sites belonging to the same type of vegetation and extremely close together, for example, PE Carlos Botelho and Onça Parda (5 km), Morro Grande and Miracatu $(70 \mathrm{~km})$ or Porto Cabral and Morro do Diabo (40km) (Table 3). The distance between the areas seems to be a determinant of beta diversity among groups with low dispersal ability such as harvestmen (Curtis \& Machado 2007). Furthermore, the vegetational formation seems to have a strong influence on the diversity of harvestmen. According to Ivanauskas et al. (2000) and Oliveira-Filho \& Fontes (2000), there is a clear floristic separation between Coastal Atlantic Rain Forest of São Paulo (a regime characterized by extremely high rainfall and no dry season) and the Atlantic Semi-deciduous Forest of the interior of the state (characterized by a lower rainfall regime and the presence of marked dry season). This separation is mainly caused by the presence of mountain ranges on the coast of the state, which keep the moisture in the Coastal part extremely high (Ivanauskas et al. 2000, Scudeller 2002). Apparently, the seasonality of rainfall is more important than the total annual precipitation in the distinction between Coastal Atlantic Rain Forest and Atlantic Semi-deciduous Forest areas (Oliveira-Filho \& Fontes 2000). This separation between the different types of vegetation can be detected in the first DCA axis (Figure 7), where there is a clear longitudinal gradient in harvestmen species distribution . The Coastal Atlantic Rain Forest areas were grouped on the left edge and savannah and semi-deciduous areas at the right end of the gradient.

A DCA analysis (Figure 7) and observation on similarity values among localities (Table 3) showed that opilionids of Atlantic Semideciduous Forests have lower alfa diversity and higher beta diversity than those observed for Atlantic Coastal forests. According to Salis et al. (1995), the vegetation of the interior of the state of São Paulo shows heterogeneous floras, with high alfa and beta diversity. High diversity of fitocenosis could be associated with a complex composition of climate and edaphic characteristics of the interior of the state of São Paulo (Salis et al. 1995).

Finally, besides the importance of distance and of the vegetation, the results obtained by similarity analysis indicate that other factors may be responsible for the distribution of harvestmen species, such as historical ones. According to Pinto-da-Rocha et al. (2005), the PE Carlos Botelho belongs to the area of endemism named South São Paulo situated on the slopes of the Serra Paranapiacaba, between the plateau and the Ribeira do Iguape river valley (DaSilva \& Pinto-daRocha. 2011).

In their study, Pinto-da-Rocha et al. (2005) and DaSilva \& Pintoda-Rocha (2011) did not recognized semi-deciduous region as area(s) of endemism in the state of Sao Paulo, which makes an understanding in regard to the historical processes related to FLONA Ipanema still 
unknown. However, large differences in climate at these locations caused by the increasing distance from the coast and consequent changes in rainfall, may have to justify their isolation of harvestmen fauna from the other areas.

\section{Acknowledgements}

We thank colleagues Alyson Ferreira, Guilherme Gomes Gois and Adriano Maia, for helpping during collecting trips. We also thank the PE Carlos Botelho guide Édipo, Ofélia de Fatima Gil Willmersdorf, head of the FLONA Ipanema and Jose Luiz Camargo Maia, director of PE Carlos Botelho. Funding FAPESP 2010/06253-0 process.

\section{References}

AB'SABER, A.N. 1970. Províncias geológicas e domínios morfoclimáticos no Brasil. Geomorfologia 20:1-26.

AB'SABER, A.N. 1973. A organização das paisagens inter e subtropicais brasileiras. Geomorfologia 41:1-39.

ALBUQUERQUE, G.B. \& RODRIGUES, R.R. 2000. A vegetação do Morro de Araçoiaba, Floresta Nacional de Ipanema,Iperó (SP). Sci. For. 58:145-159.

BEHLING, H. \& LICHTE, M. 1997. Evidence of dry and cold climatic conditions at glacial times in tropical southeastern Brazil. Quaternary Res. 48:348-358. http://dx.doi.org/10.1006/qres.1997.1932

BRAGAGNOLO, C. 2005. Diversidade e Similaridade da Fauna de opiliões a Mata Atlântica do sul e sudeste do Brasil (Arachnida: Opiliones). Dissertação de Mestrado, Departamento de Zoologia, Instituto de Biociências, Universidade de São Paulo.

BRAGAGNOLO, C., NOGUEIRA, A.A., PINTO-DA-ROCHA, R. \& PARDINI, R. 2007. Harvestman in an Atlantic forest fragmented landscapes: Evaluating assemblage response to habitat quality and quantity. Biol. Conserv. 139:389-400. http://dx.doi.org/10.1016/j. biocon.2007.07.008

BRAGAGNOLO, C. \& PINTO-DA-ROCHA, R. 2009. Os opiliões. In Patrimônio da Reserva Biológica do Alto da Serra de Paranapiacaba. A antiga Estação Biológica do Alto da Serra (M.I.M.S. Lopes, M. Kirizawa \& M.M.R.F. Melo, eds.). Instituto de Botânica, São Paulo, p.525-536.

BRESCOVIT, A.D., BERTANI, R., PINTO-DA-ROCHA, R. \& RHEIMS, C.A. 2004. Aracnídeos da Estação Ecológica Juréia-Itatins: inventário preliminar e história natural. In Estação Ecológica Juréia-Itatins. Ambiente físico, flora e fauna (O.A.V. Marques \& W. Duleba, eds.) Holos, Ribeirão Preto, p.198-221.

COLWELL, R.K. 2006. EstimateS: Stastistical estimation of species richness and shared species from samples. version 8. http://purl.oclc.org/estimates.

CURTIS, D.J. \& MACHADO, G. 2007. Ecology. In Harvestmen: the biology of Opiliones (R. Pinto-da-Rocha, G. Machado \& G. Giribet, eds.). Harvard University Press, Cambridge, p.280-308. PMid:17548861.

DASILVA, M.B. \& PINTO-DA-ROCHA, R. 2011. História biogeográfica da Mata Atlântica: opiliões (Arachnida) como modelo para sua inferência. In Biogeografia da América do Sul - Padrões e Processos (C.J.B.Carvalho, E.A.B. Almeida, org.). Roca, São Paulo, p.221-238.

FÁVERO, O.A. 2001. Do Berço da Siderurgia Brasileira à Conservação de Recursos Naturais - Um Estudo da Paisagem da Floresta Nacional de Ipanema (Iperó/SP). Dissertação de mestrado, Universidade de São Paulo, São Paulo. 257p.

GILTAY, L. 1928. Arachnides nouveaux du Brésil. Bull. Ann. Soc. R. Entomol. Belg. Entomol. 68:79-87.

HAMER, O., HARPER, D.A.T. \& RYAN, P.D. 2001. PAST: Paleontological Statistics Software Package for Education and Data Analysis. Paleontol. Elect. 4(1):9.
IVANAUSKAS, N.M., MONTEIRO, R. \& RODRIGUES, R.R. 2000. Similaridade florística entre áreas de floresta atlântica no estado de São Paulo. Braz. J. Ecol. 1-2:71-81.

JOST, L. 2006. Entropy and diversity. Opinion. Oikos 113(2):363-375. http:// dx.doi.org/10.1111/j.2006.0030-1299.14714.x

KURY, A.B. 2003. Annotated catalogue of the Laniatores of the New World (Arachnida, Opiliones). Rev. Iber. Aracnol. 1:5-337.

KURY, A.B. 2011. Order Opiliones Sundevall, 1833. In Animal biodiversity: An outline of higher-level classification and survey of taxonomic richness (Z-Q Zhang, ed.). Zootaxa 3148:112-114.

KURY, A.B. 2012. Checklist of valid genera of Opiliones of the world. Museu Nacional, UFRJ. http://www.museunacional.ufrj.br/mndi/Aracnologia/ checklaniator.htm (último acesso em 19/06/2012).

LUEDERWALDT, H. 1929. Resultados de uma excursão scientifica á Ilha de São Sebastião no littoral do Estado de São Paulo e em 1925. Rev. Mus. Paulis. 16:3-79.

MAGURRAN, A.E. 1988. Ecological diversity and its measurement. Princeton University Press, Princeton, 192p.

MELLO-LEITÃO, C.F. 1923. Arachnideos da Ilha dos Alcatrazes. Rev. Mus. Paulista 13:515-520.

MESTRE, L.A. \& PINTO-DA-ROCHA, R. 2004. Populational biology of the harvestmen Ilhaia cuspidata (Opiliones; Gonyleptidae) in an Araucaria Forest fragment (Curitiba - Paraná, Brazil). J. Arachnol. 32(2):208-220. http://dx.doi.org/10.1636/M02-61

MORELLATO, L.P.C. \& HADDAD, C.F.B. 2000. Introduction: the Brazilian Atlantic Forest. Biotropica 32(4b):786-792. http://dx.doi org/10.1111/j.1744-7429.2000.tb00618.x

OLIVEIRA-FILHO, A. \& FONTES, M.A.L. 2000. Patterns of floristic differentiation among Atlantic forests in southeastern Brazil, and the influence of climate. Biotropica 32:903-913.

PINTO-DA-ROCHA, R. 1994. Invertebrados cavernícolas da porção meridional da Província Espeleológica do Vale do Ribeira, sul do Brasil. Rev. Bras. Zool. 12(2):229-255.

PINTO-DA-ROCHA, R., BRAGAGNOLO, C. \& DASILVA, M.B. 2005. Faunistic similarity and historic biogeography of the harvestmen of southern and southeastern Atlantic Rain Forest of Brazil. J. Arachnol. 33(2):290-299. http://dx.doi.org/10.1636/04-114.1

RESENDE, L.P.A., PINTO-DA-ROCHA, R. \& BRAGAGNOLO, C. 2012. Diversity of harvestman (Arachnida: Opiliones) in Parque da Onça Parda, southeastern Brazil. Iheringia, Sér. Zool. 102(1):99-105.

SALIS, S.M., SHEPHERD, G.J. \& JOLY, C.A. 1995. Floristic comparison of mesophytic semideciduous forest of the interior of the state of São Paulo, Southeast Brazil. Vegetatio 119:155-164. http://dx.doi.org/10.1007/ BF00045595

SCUDELLER, V.V. 2002. Análise fitogeográfica da Mata Atlântica - Brasil. Tese de doutorado, Universidade Estadual de Campinas, Campinas.

SOARES, B.A.M. 1942. Contribuição ao estudo dos opiliões da Serra do Mar. Opiliões de Boracéa. Pap. Avulsos Zool. (São Paulo) 2(1):1-13.

SOARES, B.A.M. 1944a Opiliões do Alto da Serra. Pap. Avulsos Zool. (São Paulo) (16):221-242.

SOARES, B.A.M. 1944b. Mais alguns opiliões de Boracéia. Pap. Avulsos Zool. (São Paulo) (12):177-186.

SOARES, H.E.M. 1966. Opiliões das ilhas dos Búzios e Vitória (Opiliones: Gonyleptidae, Phalangodidae). Pap. Avulsos Zool. (São Paulo) 19(25):279-293.

TRAJANO, E. \& GNASPINI, P. 1991. Composição da fauna cavernícola brasileira, com uma análise preliminar da distribuição dos táxons. Rev. Bras. Zool. 7(3):383-407. http://dx.doi.org/10.1590/S010181751990000300017 